\title{
State Legislative Ideology \& the Preemption of City Ordinances: The Case of Worker Rights Laws*
}

\author{
Christopher B. Goodman ${ }^{\dagger} \quad$ University of Nebraska at Omaha
}

This article discusses the influence of state legislative ideology on the legislative preemption of local ordinances in the area of worker rights. States define the powers of local governments within their purview and states may use this power to restrict local governments from pursuing certain policies. Using data on state legislative activity and ideology from 1993 to 2016, I find within-state increases in legislative ideology, indicating increased legislative conservatism, associated with an increased risk of preempting local government policy, all else equal. This finding is robust to a number of alternate specifications and hypotheses. Ideology appears to play an important role in the decision to involve the state in the affairs of local governments.

Keywords: preemption, state legislatures, local autonomy, minimum wage

\section{Introduction}

In recent years, the relationship between state and local governments in the United States has become increasingly strained. City governments, typically more liberal than their state, seek to enact policies to satisfy city voters; however, generally more conservative state legislatures find themselves at odds with these local ordinances and seek to prevent their implementation. This arrangement necessarily leads to conflict, but such conflict is between unequal contestants. State legislatures determine the basic rules of the game for local governments including what kinds of local policies can be adopted. Local governments usually have little recourse against such state actions, but this does not prevent them from attempting to use the judicial system as a remedy.

There are many state-specific examples of such actions. Possibly the most visible is the action the North Carolina legislature took against a City of Charlotte ordinance banning discrimination against LGBT individuals. In 2016, the legislature convened a special legislative session to pass a law preventing the implementation of the City of Charlotte ordinance and preventing any additional municipalities from enacting similar laws. This preemption gained national notoriety that ultimately lead to the repeal of both the Charlotte ordinance and the state law. Battles between more liberally minded city government and more conservative minded state government are not uncommon, but this example begs the question of how systematic this relationship really is. This analysis seeks to answer this question of whether there is a systematic relationship between state legislative ideology and the legislative preemption of local ordinances in the area of workers rights laws using an event history framework.

While the literature on the relationship between state and local governments is voluminous, there is limited empirical research on the state preemption of local laws. Trapenberg Frick, Weinz-

${ }^{*}$ Preliminary Draft. Please do not cite or circulate without author's permission.

${ }^{\dagger}$ Version: 31 January 2019 
immer, and Waddell (2015) examine the factors associated with state opposition to UN Agenda 21. While not exactly preemption (it is unclear what potential local laws might be preempted), they find no evidence of ideological influence in the opposition. Riverstone-Newell (2017), through a series of case analyses, concludes that much of the recent preemption activity has been driven by an ideological difference between progressive cities and more conservative state legislatures. Most recently, Swanson and Barrilleaux (2018) examine court driven preemption activity and find ideological differences between cities and states to be an important factor in courts overturning local laws; however, strong home rule powers can temper this. Ultimately, none of the recent work on state preemption of local laws takes the issue from the legislative perspective and a quantitative manner.

This analysis adds a number of contributions to the literature. First, it expands the nascent literature on state preemption of local laws. The literature is currently small; however, the issue is timely and policy relevant. There is intense media scrutiny of preemption battles; however, the literature as it currently stands is largely unhelpful in informing these debates. Second, this analysis is the first of its kind to directly examine the factors associated with passage of state laws preempting local action using an event history framework (Berry and Berry 1990). This approach brings a rich set of tools to use to analyze the issue. Finally, I focus on a specific policy area, workers rights, that is both salient and relevant to voters on both sides of the political spectrum.

The analysis proceeds as follows. First, the previous literature on state-local relations is examined. Special attention is paid to local autonomy and how state legislatures treat local governments. Next, the data on worker rights related preemptions from Economic Policy Institute (2018), state legislative ideology from Shor and McCarty (2011), and others are outlined and the empirical model of state preemptions of workers rights laws from 1993 to 2016 is specified. Results are presented and number of extensions are explored. Finally, implications are discussed.

\section{Background}

\section{State-Local Relations in the U.S.}

Local governments in the United States are constructs of their respective states. States decide the relative level of autonomy that different forms of local government are endowed with. This relationship between state and local governments has been recognized by federal and state courts since Judge John Dillion's 1868 court ruling in City of Clinton v. Cedar Rapids \& Missouri River Railroad. In a series of court cases, Dillon lays out a doctrine of complete subservience of municipal corporations to state legislatures. As Bowman and Kearney $(2014,3)$ explain, the strictest interpretation of Dillon's Rule means "any doubt regarding the legality of a specific local government power is resolved in favor of the state." Currently, 39 states have adopted Dillion's rule. In 31 states, Dillion's Rule applies to all local governments and in 8 states it applies to specific jurisdictions (Richardson 2011).

Even in Dillion's Rule states, some state legislatures have granted local governments home rule powers that allow local areas to tailor their public policies to meet local needs without consultation with the state legislature. For a time concurrent with Judge Dillion's ruling, there was a legal movement to allow local government the powers of self-government, largely free of interference from the state. Known as the Cooley Doctrine, this approach to local government autonomy has faded as a legal doctrine once Dillion's Rule was upheld by the U.S. Supreme Court (Richardson 2011). Nonetheless, states have continued to grant limited home rule powers to their local govern- 
ments. In doing so, states have not completely given up their oversight powers, but rather have decided some areas of oversight are less important than others. Currently, 48 states grant some or all local governments home rule powers; however, the amount of powers and local government's ability to access them vary highly by state.

There is a rich literature attempting to determine the exact nature of local autonomy among the states. Given the legal and political ambiguity of home rule powers, this is no small feat. In general, it is thought that local governments have been losing power and authority to states for the last 40 years. Stephens (1974) outlines (and Bowman and Kearney (2011) updates) a measure of state centralization composed of three dimensions: fiscal responsibility, service delivery, and public personnel. Each dimension measure the balance between state responsibility and local government responsibility. The trend from 1957 until 2008 is increasing centralization among the three dimensions; however, there is interstate variation. As Bowman (2017) notes, some states have become considerably more centralized while others have become more decentralized. Perceptual measures of centralization also point to a loss of local autonomy (Bowman and Kearney 2012).

Given Dillion's Rule, the granting of limited home rule powers, and changes in state centralization over time, local governments are at a disadvantage relative to the state in matters of local policy making. This relationship necessarily leads to conflict between local governments and the state. The changing political landscape at the state (trending more conservative) and local levels (trending more liberal) amplify this conflict as the two sides see each other as political adversaries (Einstein and Glick 2017). This is a marked departure from previous time periods when local government exerted significant lobbying pressure on state legislatures (Berman 2003).

\section{The Role of State Legislatures}

As local governments are constructs of the state, state legislatures play a large role in determining how local governance will be arranged. Historically, state legislatures have spent a large amount of time considering issues of local affairs (Burns and Gamm 1997). Between 1871 and 1921, state legislatures in Alabama, Massachusetts, and Michigan had numerous committees related to local affairs and between 25 to 50 percent of legislation pertained to local issues. Burns et al. (2009) note the prominence of legislation related to local affairs continues in state legislatures and the importance of such legislation cannot be understated. Burns et al. (2009) go as far as contending "local policy outcomes often occur in the state legislature." They further find that unity among the urban delegation with respect to "big city" bills limits conflict about such bills and allows the urban delegation to manage the legislative process effectively. The effects of disunity among the urban delegation can spell disaster for local specific legislation (Gamm and Kousser 2013). Larger urban delegations often break along party lines and these cleavages can spell doom for urban related legislation. As Gamm and Kousser (2013) explain, this process only gets worse the larger the urban delegation is. Lovrich and Newman (2004) find legislators with prior local government experience are more attentive to local issues in the state legislature and this previous service can potentially moderate any disunity effects.

Bowman and Kearney (2014) describe the more recent (2011-2012 biennium) treatment of local governments in state legislatures. They find nearly 2,500 new laws pertaining to general purpose local governments (excluding school districts and special districts) with high variance among states. These laws are classified as "empowering" or "restricting" as to give an average of statespecific legislation related to local governments. During the 2011-2012 biennium, 33 states em- 
powered local governments, 12 restricted them, and in five states, empowering and restricting legislation cancels out. Bowman (2017) notes that the legal status of local governments (Dillion's Rule or home rule) is not influential in the passage of empowering or restricting legislation. In general, the prevalence of local legislation in state legislatures has been declining over the 20th century; however, local bills still made up 20 percent of all legislation in 2000 (Gamm and Kousser 2010). While legislatures have put local affairs on the back burner, they are still active in the management of local government affairs.

\section{Preemption of City Ordinances}

What is clear from the preceding discussion is state legislatures are in control of local governments' destinies and they have been increasingly willing to move powers away from local governments. At the same time, residents strongly support empowering local governments to solve local problems (Schneider, Jacoby, and Lewis 2011). Among those scholars who study local autonomy, the general consensus is, absent a compelling reason for state centralization," "[1]ocal decisions are best made by locals" (Hooghe and Marks 2009, 232). Local governments generate a significant amount of policy innovation; solving local problems with local ideas (Frug and Barron 2008). Unsurprisingly, municipal officials also feel the local level is the best place for policy decisions to be made (DuPuis et al. 2018).

As Frug and Barron (2008) note, the current legal structure in most states affords local governments too little flexibility to effectively solve local problems. At the same time, state legislatures do not debate local issues in a serious or nuanced manner leaving local governments in a bind. Local governments can push forward with dubious legal authority or leave local voters' demands unfulfilled. In more recent years, local governments have turned to the former, adopting policies with dubious legal authority to do so.

When a local government wanders into policy territory that a state believes is inappropriate, the state is faced with a choice of what to do. If a state believes a local government has stepped outside of its current legal authority and this is clearly defined in law, a state may use the courts to enforce current rules (Swanson and Barrilleaux 2018). This method of preemption, court-driven preemption, requires a local ordinance to be adopted to begin the process. A plaintiff may view a local ordinance as unfair and sue to stop its enforcement; however, the courts may find such laws to be consistent with current state law. Therefore, this method does not guarantee preemption. The second mechanism is legislatively-driven preemption. This method of preemption requires no specific action be taken by a local government; however, legislative preemption is often spurred by the passage or threat of passage of a particular local ordinance. Under this method of preemption, a state legislature alters the rules of the game for local governments, reducing their legal authority to enact local ordinances in particular area. ${ }^{2}$ More recent legislatively driven preemptions often include punitive measures against local governments should they decide to challenge or defy a new state law (Phillips 2017; Briffault 2018). These include withholding state aid or other financial penalties, holding local officials personally liable should they defy state law, and limiting the avenues local governments have to legally challenge state preemptions. Legislatively-driven preemption is the focus of this analysis.

\footnotetext{
${ }^{1}$ Examples include eliminating spillovers, issues of fiscal equivalence, or incompetent and/or corrupt local officials.

${ }^{2}$ More recently, some states have turned to "blanket preemption" or "nuclear preemption" that significantly reduces local authority on a variety of issues (Riverstone-Newell 2017; Briffault 2018). From a local autonomy perspective, it is unclear if these actions are preemption or a fundamental restructuring of home rule powers.
} 
The distinction between the two forms of state preemption of local ordinances is important. ${ }^{3}$ Court-driven preemption requires a specific local ordinance to be passed. When a state decides to sue to block implementation of a local ordinance, it is essentially asking the courts to more specifically define the meaning of an existing state law. This action does not necessarily indicate any partisan intent (though it might, see Swanson and Barrilleaux (2018)), but rather inconsistency with the legal authority granted to local governments under existing law. Legislatively-driven preemption can be viewed through a partisan lens as these preemptions are explicit actions taken by partisan actors. In instances where legislative preemption is not a reaction to a specific local ordinance, one might view this as entirely partisan. ${ }^{4}$ The two kinds of preemption often lead to the same outcome, blocking of a local ordinance; however, the motivations to engage in preemption and the process by which the preemption is achieved are completely different. Examining legislatively-driven preemption requires examining factors associated with state legislatures.

Indeed, most observers suggest the more recent legislative preemptions are conflicts between more liberal local officials and more conservative state legislatures. Relevant to this analysis, Langan and McFarland (2017) find liberal cities are more likely to adopt city minimum wage ordinances, all else equal. Ordinances of these kind are often preempted by more conservative state legislatures (Riverstone-Newell 2017; Phillips 2017); however, there is little empirical evidence of this connection. The question remains why a state legislature would go the route of preempting a local ordinance legislatively rather than through the courts. Related specifically to worker rights legislation, corporate interests and conservative interests are often highly intertwined (HertelFernandez 2016). For instance, prominent business associations such as the National Restaurant Association (2014) and the National Retail Federation (2014) oppose increases in local, state, and federal minimum wages; a policy position generally held by conservative legislators. These free market policies are often packaged and distributed to more conservative state legislators via groups like the American Legislative Exchange Council (ALEC) and the U.S. Chamber of Commerce (Hertel-Fernandez 2016). These organizations have had some success at influencing their legislative members to introduce and pass legislation in their respective states consistent with the organization's pro-business policy preferences (Hertel-Fernandez 2014; Riverstone-Newell 2017). If this is the case, one might expect more conservative state legislatures to be more active in preempting worker rights related local ordinances. A second potential mechanism is preemption allows more conservative state legislators to "build their reputations by exploiting symbolic issues" (Hicks et al. 2018, 29). With few electoral repercussions for conservative state legislators, pushing for legislative preemption is a way to signal their conservative bona fides and attract attention. ${ }^{5}$

This process of learning via national groups points to further policy diffusion related influences as potential predictors of legislative preemption. Chief among these are differences in political institutions among state legislatures (Boushey 2010). Given that ALEC often produces model legislation for its legislative members, ${ }^{6}$ the professionalism of a state legislature is likely influential in the preemption of local ordinances. Jansa, Hansen, and Gray (forthcoming) has found evidence that less professional legislatures are more likely to copy from other adopters. The combination of these two forces suggests there may be a negative relationship between professionalism and

\footnotetext{
${ }^{3}$ Briffault (2018) refers to this distinction as "old" (court-driven) and "new" (legislatively-driven) preemption.

${ }^{4}$ This is a concept referred to as "preemptive preemption" by Phillips (2017).

${ }^{5}$ It should be noted this works for big city (often Democratic) mayors. There is much electoral benefit to openly defying conservative state legislatures.

${ }^{6}$ ALEC has model legislation specific to the preemption of local minimum wage ordinances. See https://www.alec.org/model-policy/living-wage-mandate-preemption-act/.
} 
preemption. That is, less professionalized legislatures may be more likely to preempt. Political competition may also be influential on preemption activity. Reduced political competition lessens the electoral consequences of unpopular votes. In so much as preemption is political unpopular, lower levels of political competition at the state level could provide cover. I next turn to answering the empirical question of whether more conservative state legislatures are more active in legislatively preempting local worker rights ordinances.

\section{Data \& Empirical Strategy}

\section{Data}

Data on state preemption of local ordinances is difficult to track. As of yet, there is no centralized repository of information on state preemption activity. The National League of Cities provides likely the most comprehensive database of preemption activity (DuPuis et al. 2018); however, the data as reported are too limited to build a cross-sectional, time-series dataset. Swindell, Svara, and Stenberg (2018) and Swindell, Stenberg, and Svara (2017) maintain a similar dataset, but it is not public. In order to facilitate analysis, information on legislative preemptions in five policy areas related to workers rights are selected. These data are compiled and tracked by the Economic Policy Institute (2018). In each case, a preemption is registered if a state passes a law limiting the implementation of any of the five policies. The five polices include minimum wage, fair scheduling, project labor agreements, prevailing wage, and paid leave. The primary dependent variable for this analysis is any preemption of any kind over the time period, 1993 to 2016. As such, this is a dichotomous variable indicating zero if there are no preemptions in a given year and one if there are any in a given year. ${ }^{7}$ The geographic distribution of these data can be seen in Figure 1. There are numerous states who have yet to legislatively preempt any of the five policies; however, there is variation with two states (Kansas, Michigan) over the 23 year time period preempting all five. As can be seen in Figure 2 and Table 1, preemption of local minimum wage ordinances is the most prevalent and consistent over time; however, the other four types have become common in recent years. Legislatively-driven preemption of local paid leave ordinances lead this group of recent legislation. ${ }^{8}$

Until relatively recently, data on state legislative ideology was severely lacking. The most popular method of assessing government ideology was the method outline in Berry et al. (1998). This method weights average state party proportions and multiplies them by state delegation congressional ideology. This translation is imperfect as congressional ideology does not necessarily translate to state legislative ideology. This issue is remedied by the work of Shor and McCarty (2011). They provide state legislator ideal points based on state legislative roll call voting and the Project Vote Smart National Political Awareness Test (NPAT). The data are available for years 1993 to 2016. This analysis uses aggregations of the individual ideal points as the preferred measure of

\footnotetext{
${ }^{7}$ This necessarily limits variation in the preemption activity of a state. Theoretically, a state may have as many as five preemptions in a given year. This approach is nearly identical to the pooled components analysis in Boehmke (2009), allowing to repeat adoption of similar components. Relaxing this restriction to examine the count of adoptions in any given state-year is explored in a later section.

${ }^{8}$ There is some indications this spat of paid leave preemptions is tied to Wisconsin Bill 23, passed in 2011, to preempt the City of Milwaukee's local paid leave ordinance passed by local referendum in 2008. The text of this legislation was distributed by ALEC (though it was never officially part of the groups' model legislation) and may have been adopted, in part, by numerous other states (Grabar 2016).
} 
Figure 1: State Preemption of City Ordinances related to Worker Rights, 1993-2016

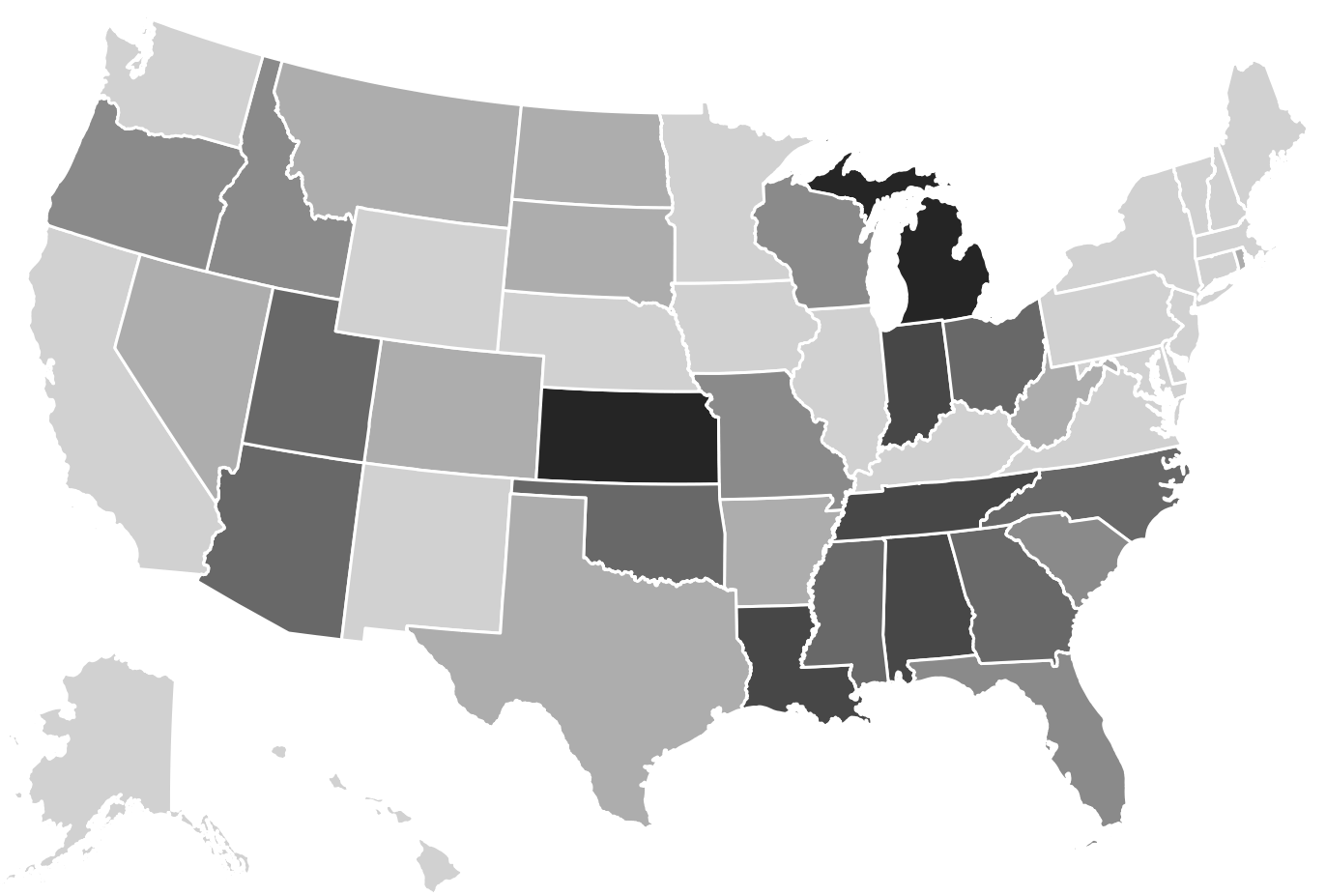

Number of Preemptions

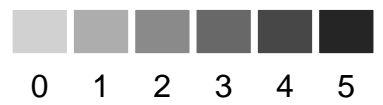

state legislative ideology. Specifically, the median ideal point for each legislative chamber majority party is used as the measure of legislative ideology. ${ }^{9}$ Shor and McCarty's ideology measure is centered on zero with scores below signifying more liberal majorities and scores above zero indicating more conservative majorities. As is seen in Table 1, legislative majorities in both chambers have a slight conservative tilt, but there is much variation around the mean. Figure 2 plots legislative ideology, averaged across 49 state houses, across time. Average majority ideology becomes sharply more conservative in the aftermath of the 1994 Republican Revolution and again in the aftermath of the 2010 election cycle. Mapped on top of legislative preemption activity, the rise of conservative dominated legislatures tracks well with preemption activity, particularly in the latter time periods. Naturally, this visual relationship does not demonstrate a statistical relationship.

\footnotetext{
${ }^{9}$ This restriction to only the majority party in each chamber is relaxed in the extensions section
} 
Figure 2: State Preemption and Average Legislative Ideology, 1993-2016

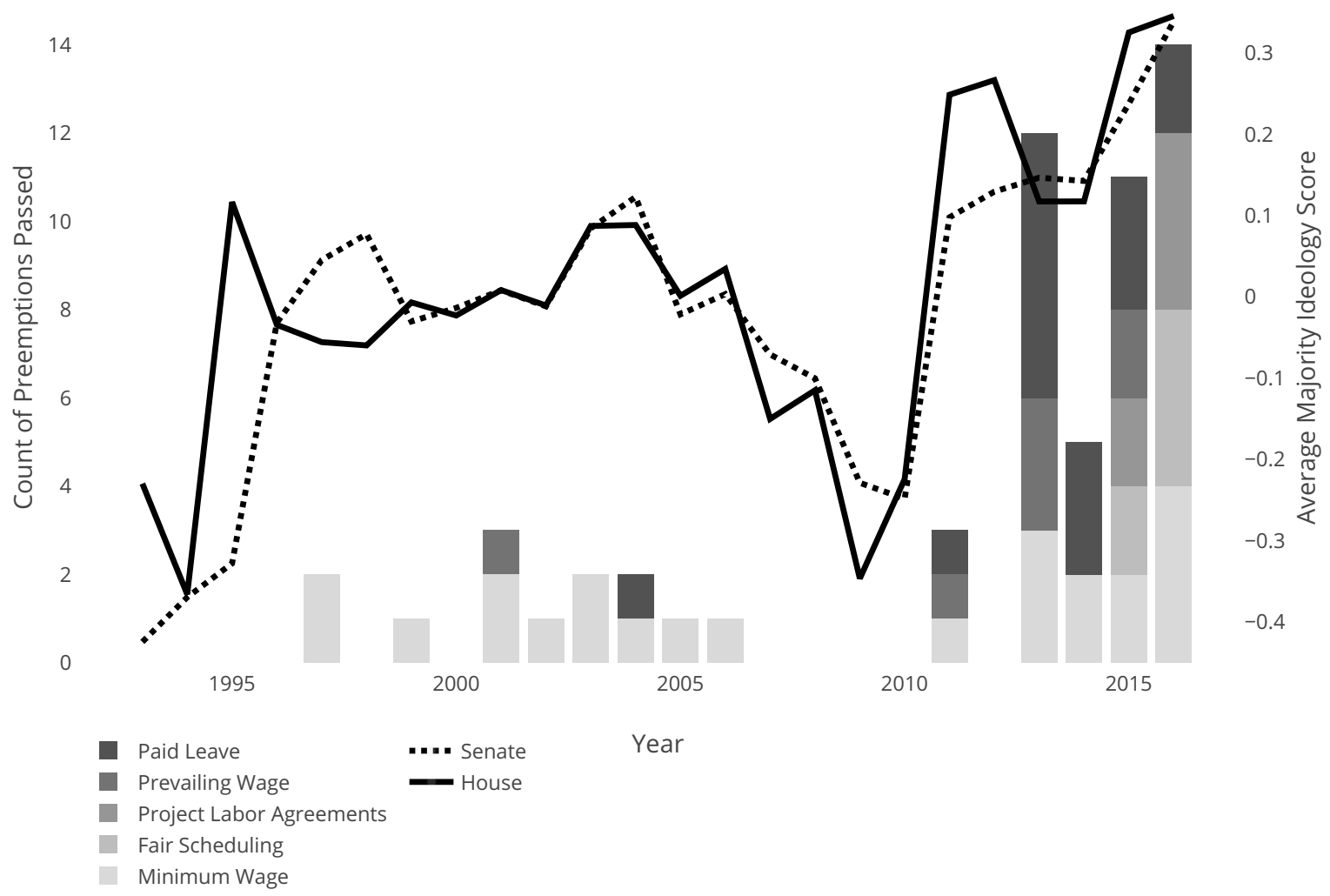

Of course, state legislative ideology is not the only likely predictor of legislative preemption activity in the area of worker's rights. From the policy diffusion literature (Boushey 2010), there are a number of political institutions that are likely important. First is state legislative professionalism. As Jansa, Hansen, and Gray (forthcoming) note, less professional legislatures are more likely to "copy and paste" legislation from other sources. Given that preemption legislation may diffuse from organizations like ALEC, professionalism may be an important predictor. If this is indeed the case, one expects increased professionalism to be a negative predictor of legislative preemption activity. Professionalism is operationalized using Squire's index of legislative professionalism. It is interpreted as state legislative professionalism relative to congressional professionalism (Squire $1992,2000,2007,2012,2017)$. On average, professionalism is low at approximately 20 percent of congressional professionalism. The second institution is political competition. If state legislative races are reasonable competitive, legislators may perceive there to be an electoral cost for contentious votes. This could limit preemption activity. Political competition is operationalized using a folded Ranney index as calculated in Bibby and Holbrook (2004) with a four year moving average. ${ }^{10}$ A value of 0.50 indicates complete one party control and as the index approaches one, political competition increases. On average, the index takes on a value of 0.85 indicating a reasonable amount of competition; however, the mean value hides a reduction of average competition and an increase in the variation over the time period.

\footnotetext{
${ }^{10} \mathrm{~A}$ folded Ranney index is calculated as $1-\mid 0.5$ - Ranney Index $\mid$. Longer moving averages (6 year and 10 year) were tested and there is no appreciable difference in results.
} 
In addition to political institutions, there are a number of control variables. Population is included to control for the size of state. Personal income per capita is included to control for potential wealth effects. Two variables are included to control for the size and/or prevalence of urban populations. The first is population density. The second is the percentage of the state population living in urban areas (as defined as living in a metropolitan county). These two variable are similar, but measure different concepts. Density measures the prevalence of urban areas in a state. As average density increases, more of the physical landscape of the state is urban. Urban population measures how much of the state population lives in these areas. Rural states typically have low average density but a high percentage urban residents. Given the discussion above about the importance (or lack thereof) of urban legislative delegations, these two variables provide important controls for the ability of state legislators representing cities to fend off preemption.

A number of variables are included to control for various characteristics of state residents. First, both the percentage of residents who are under the age of 19 and over the age of 65 are included. The prevalence of such residents may shift legislator's time away from issues of workers and toward issues of youth or the elderly. The percentage of the state's population with 16+ years of education is included to control for educational endowments. Racial heterogeneity of the population is included. This is operationalized following Alesina, Baqir, and Easterly (1999) as the probability that two randomly drawn individuals belong to two different ethnic groups. ${ }^{11}$ Union membership density is an important control for the power of relevant interest groups. Many of the policy issues potentially preempted are of importance to union members and unions may exert lobbying pressure to prevent their preemption. The variable is supplied by Hirsch and Macpherson (2003) and is extracted from the Current Population Survey, Annual Social and Economic Supplement. Lastly, following Boehmke (2009), the regressions to follow are conditioned on the number of worker rights related preemptions a state has already adopted. It is unclear whether prior experience with preemption increases the likelihood of preemption in the future or reduces it.

The main data sources for this analysis are the Economic Policy Institute (2018) enumerations of preemptions and state legislative ideology data from Shor and McCarty (2011). These are supplemented by Squire, Census Bureau estimates, the Surveillance, Epidemiology, and End Results program at the Centers for Disease Control, and the Regional Economic Information System at the Bureau of Economic Analysis. On the first cut, Nebraska is eliminated from the dataset due to its unicameral legislature. A further twenty states are eliminated because they have no preemption activity over the 1993 to 2016 time period. This is necessitated by the maximum likelihood estimation technique outlined below. This data reduction method leaves a final analytical dataset of 592 observations from 29 states. Data sources and summary statistics for all of the variables are reported in Table 1.

\section{Empirical Strategy}

Event history analyses have a long and rich history in the political science literature (Berry and Berry 1990). The standard methodology involves specifying the dependent variable as dichotomous $[0,1]$ and regressing using logit or probit. Given the cross sectional, time series nature of the

\footnotetext{
${ }^{11}$ Ethnic fragmentation is calculated as follows: ETHNIC $=1-\sum_{i}\left(R A C E_{i}\right)^{2}$ where Race $_{i}$ denotes the share of population for race $i$ where $i=\{$ white, black, Native American, and Asian $\}$. See Alesina, Baqir, and Easterly (1999) for further explanation of the construction of this variable and Vigdor (2002) for a theoretical perspective.
} 
Table 1: Summary Statistics

\begin{tabular}{|c|c|c|c|c|c|c|c|}
\hline Variable & Source & Units & Mean & p25 & p50 & p75 & Std Dev \\
\hline Any worker rights related preemption & EPI & Indicator, 0 or 1 & 0.041 & 0.000 & 0.000 & 0.000 & 0.198 \\
\hline Minimum wage preemption & EPI & Indicator, 0 or 1 & 0.019 & 0.000 & 0.000 & 0.000 & 0.137 \\
\hline Fair scheduling preemption & EPI & Indicator, 0 or 1 & 0.004 & 0.000 & 0.000 & 0.000 & 0.064 \\
\hline Project labor agreement preemption & EPI & Indicator, 0 or 1 & 0.014 & 0.000 & 0.000 & 0.000 & 0.118 \\
\hline Prevailing wage preemption & EPI & Indicator, 0 or 1 & 0.006 & 0.000 & 0.000 & 0.000 & 0.076 \\
\hline Paid leave preemption & EPI & Indicator, 0 or 1 & 0.013 & 0.000 & 0.000 & 0.000 & 0.111 \\
\hline State house majority median & ShMc & Common Space & 0.067 & -0.463 & 0.195 & 0.606 & 0.616 \\
\hline State senate majority median & ShMc & Common Space & 0.069 & -0.463 & 0.195 & 0.613 & 0.602 \\
\hline Legislative professionalism & Squire & Fraction & 0.193 & 0.115 & 0.164 & 0.227 & 0.125 \\
\hline Folded Ranney index & $\mathrm{BH}$ & Fraction & 0.845 & 0.791 & 0.840 & 0.904 & 0.080 \\
\hline Population & Census & $1000 \mathrm{~s}$ & 5858.24 & 1700.29 & 4087.93 & 6669.06 & 6460.58 \\
\hline Personal income, per capita & REIS & $\$ 1,000$ & 41.767 & 36.552 & 40.623 & 46.152 & 7.410 \\
\hline Population density & Census & Ratio & 188.077 & 40.799 & 94.622 & 206.042 & 253.684 \\
\hline$\%$ Urban population & Census & Fraction & 0.717 & 0.593 & 0.738 & 0.863 & 0.192 \\
\hline$\%$ Population over 65 & SEER & Fraction & 0.132 & 0.121 & 0.133 & 0.144 & 0.020 \\
\hline \% Population under 19 & SEER & Fraction & 0.276 & 0.262 & 0.275 & 0.288 & 0.023 \\
\hline \% College degree & CPS-ASEC & Fraction & 0.231 & 0.196 & 0.224 & 0.262 & 0.049 \\
\hline Ethnic fractionalization index & SEER & Fraction & 0.273 & 0.159 & 0.266 & 0.401 & 0.136 \\
\hline Union membership density & CPS-ASEC & Fraction & 0.119 & 0.070 & 0.110 & 0.160 & 0.057 \\
\hline
\end{tabular}

Notes: EPI = Economic Policy Institute; ShMc = Shor and McCarty (2011); Census = Census Bureau; REIS = Regional Economic Information System; SEER = Surveillance, Epidemiology, and End Results program; Squire = Squire, multiple years; $\mathrm{BH}=\mathrm{Bibby}$ and Holbrook; CPS-ASEC = Current Population Survey - Annual Social and Economic Supplement. Data are for 49 states from 1993 to 2016 excluding Nebraska.

data, unit specific fixed effects are necessary to control for any time-invariant, unobserved heterogeneity (Green, Kim, and Yoon 2001). In doing so, the baseline rate of adoption is allowed to vary by state (Boehmke 2009); something that is likely important given that some local policies (minimum wage or paid leave) are preempted by a great many states while others (fair scheduling) are not. ${ }^{12}$ The methods typically used are thought to suffer from an incidental parameters problem (Neyman and Scott 1948). Rather than rely on a single estimation technique, a varied approach is used. Following the advice of Beck (2015) for the estimation of binary dependent variables with fixed effects, a linear probability model with state and year fixed effects is used (Angrist 2001), conditional logit (Chamberlain 1980), and logit with state fixed effects. ${ }^{13}$ The results from the three estimation techniques will be used to corroborate the findings across models. To aid in comparison between the three techniques, I constrain the OLS sample to those states that exhibit some time series variation. As Beck (2015) explains, not doing so likely biases the $\beta$ coefficient toward zero as the marginal effects of this "ALL0" group are zero. This procedure eliminates 20 states from the dataset. ${ }^{14}$ The OLS and logit techniques allow for the recovery of marginal effects; however, the conditional logit does not.

\footnotetext{
${ }^{12}$ This is a departure from a large portion of the event history or policy diffusion literature that tends to estimate these models using pooled analyses (Shipan and Volden 2008). Given the primary hypothesis of this analysis is that within-state increases in conservatism is a correlate of preemption activity, a fixed effects approach is necessary.

${ }^{13}$ The latter is estimated in Stata using the log it fe command and the analytical corrected estimator. Average partial effects are displayed throughout.

${ }^{14}$ The OLS results presented in table 2 are qualitatively robust to the inclusion of all states. As Beck (2015) predicts, the effect size on the two primary variables of interest are biased downward. The effect size of state senate majority median is lower by roughly 0.02 units and statistically significant at the 0.01 level. The effect size on state house majority median is halved and statistically significant at the 0.05 level.
} 


\section{Results}

Table 2 shows the results of three regression or logit models where the dependent variable is binary, indicating one if a state had a legislative preemption of any kind in a given year. The first specification in estimated using OLS. The second specification is estimated using conditional logit and the third specification is estimated using fixed effects logit. Across all three specifications, both upper and lower house majority ideology variables are positive suggesting increasing within-state conservatism in either chamber is associated with higher risk of preemption in any given year. While the results are generally consistent (models 1 and 3 are directly comparable as marginal effects), the results are fairly fragile with only house majority ideology rising to the level of 95 percent significance across all three specifications. The marginal effects between models 1 and 3 are quite similar with an increase of 1 unit in house ideology (neutral (0) to conservative (1)) associated with a 5 to 6 percent increase in the risk of preemption. In specification one, senate majorities rise to the level of statistically significance with a one unit increase in ideology associated with a 6.5 percent increase in the risk of preemption. Taken as a pair, house and senate majority ideology are jointly different than zero.

Legislative professionalism exerts no statistical influence on the risk of preemption and political competition exerts a statistically inconsistent yet negative influence on the risk of preemption. This result is intriguing as previous work on the policy diffusion has found these factors to be influential on the receptivity of states to adopting policy innovations (Boushey 2010). It is possible the overtly conservative nature of the groups developing and diffusing the model legislation many of these preemptions are based minimizes the influence of these institutions. The results suggest that state legislatures that are more electorally competitive see a lower risk of preemption; potentially indicating there is an electoral risk to preemption in this policy area. However, this finding is not supported by all specifications, reducing confidence in the finding. The remaining control variables are largely not influential on preemption activity. Population exerts a negative influence suggesting that larger states are less willing to preempt local government actions. Increased ethnic heterogeneity is associated with high probability of preemption. This result may signal a legislature's willingness to preempt the policies of more diverse urban areas; however, this particular variable is too crude of a measure to answer that exact question. Lastly, previous experience with preemption reduces the risk of future preemption.

\section{Extensions}

The results presented in the previous section provide evidence of a link between increasingly conservative state legislatures and legislative preemption activity in the realm of worker rights policies. This section tests a number of extensions to this analysis and explores the sensitivity of the results to alternative specifications. First, examining state legislative ideology from the perspective of the majority party eliminates the possibility of bipartisan preemption activity. This is explored by re-specifying the models presented in Table 2 using upper and lower chamber ideology rather than majority ideology. Second, state legislative chambers do not make law in isolation. It is possible the combination of upper and lower house ideology is what is truly important. Following Shor and McCarty (2011), upper and lower house ideology are averaged and the original models re-estimated. Third, the influence of both legislative ideology and gubernatorial ideology is examined. Since a successful preemption requires action from three bodies, the alignment of 
Table 2: Any worker rights preemption, 1993-2016

\begin{tabular}{|c|c|c|c|}
\hline Variable & $\begin{array}{c}(1) \\
\text { OLS }\end{array}$ & $\begin{array}{c}(2) \\
\text { CLOGIT }\end{array}$ & $\begin{array}{c}(3) \\
\text { FELOGIT }\end{array}$ \\
\hline \multicolumn{4}{|l|}{ Ideology } \\
\hline State house majority median & $\begin{array}{c}0.0522^{*} \\
(2.05)\end{array}$ & $\begin{array}{c}1.7235^{*} \\
(2.39)\end{array}$ & $\begin{array}{c}0.0621^{*} \\
(1.98)\end{array}$ \\
\hline State senate majority median & $\begin{array}{c}0.0657^{*} \\
(2.32)\end{array}$ & $\begin{array}{c}1.9253 \\
(1.84)\end{array}$ & $\begin{array}{c}0.0690 \\
(1.78)\end{array}$ \\
\hline \multicolumn{4}{|l|}{ Political Institutions } \\
\hline State legislative professionalism & $\begin{array}{c}-0.1082 \\
(-0.61)\end{array}$ & $\begin{array}{c}-5.7462 \\
(-1.04)\end{array}$ & $\begin{array}{c}-0.2078 \\
(1.12)\end{array}$ \\
\hline Political competition & $\begin{array}{c}-0.2191 \\
(-1.18)\end{array}$ & $\begin{array}{c}-12.1795^{*} \\
(-2.27)\end{array}$ & $\begin{array}{c}-0.4397^{*} \\
(1.96)\end{array}$ \\
\hline \multicolumn{4}{|l|}{ Economics E Demographics } \\
\hline Population (1000s) & $\begin{array}{c}-0.0001^{* *} \\
(-4.16)\end{array}$ & $\begin{array}{c}-0.0035^{* *} \\
(-2.60)\end{array}$ & $\begin{array}{c}-0.0001^{*} \\
(2.09)\end{array}$ \\
\hline Personal income, per capita & $\begin{array}{c}-0.0096 \\
(-1.21)\end{array}$ & $\begin{array}{c}-0.0042 \\
(-0.03)\end{array}$ & $\begin{array}{c}-0.0002 \\
(0.04)\end{array}$ \\
\hline Population density & $\begin{array}{c}0.0022 \\
(1.40)\end{array}$ & $\begin{array}{c}0.0854 \\
(1.31)\end{array}$ & $\begin{array}{l}0.0031 \\
(1.30)\end{array}$ \\
\hline \% Urban population & $\begin{array}{c}-0.0902 \\
(-0.35)\end{array}$ & $\begin{array}{c}0.2897 \\
(0.03)\end{array}$ & $\begin{array}{c}0.01201 \\
(0.04)\end{array}$ \\
\hline \% Population over 65 & $\begin{array}{c}-3.1766 \\
(-0.68)\end{array}$ & $\begin{array}{c}88.0430^{*} \\
(2.18)\end{array}$ & $\begin{array}{c}3.1753 \\
(1.91)\end{array}$ \\
\hline \% Population under 19 & $\begin{array}{l}1.2669 \\
(0.38)\end{array}$ & $\begin{array}{c}-4.4104 \\
(-0.08)\end{array}$ & $\begin{array}{c}-0.1517 \\
(0.09)\end{array}$ \\
\hline$\%$ College degree & $\begin{array}{c}0.7948 \\
(0.89)\end{array}$ & $\begin{array}{l}1.1018 \\
(0.07)\end{array}$ & $\begin{array}{c}0.0443 \\
(0.09)\end{array}$ \\
\hline Ethnic fractionalization index & $\begin{array}{c}0.6973 \\
(0.69)\end{array}$ & $\begin{array}{c}138.5001^{* *} \\
(3.59)\end{array}$ & $\begin{array}{c}4.9703^{*} \\
(2.44)\end{array}$ \\
\hline Union membership density & $\begin{array}{c}0.7746 \\
(0.60)\end{array}$ & $\begin{array}{c}37.5884 \\
(1.69)\end{array}$ & $\begin{array}{c}1.3636 \\
(1.62)\end{array}$ \\
\hline Number of previous preemptions & $\begin{array}{c}-0.1290^{* *} \\
(-4.30)\end{array}$ & $\begin{array}{c}-2.5998^{* *} \\
(-5.08)\end{array}$ & $\begin{array}{c}-.0934^{* *} \\
(2.67)\end{array}$ \\
\hline$N$ & 592 & 575 & 575 \\
\hline Number of states & 29 & 28 & 28 \\
\hline Within/Pseudo- $R^{2}$ & 0.109 & 0.459 & 0.417 \\
\hline
\end{tabular}

Notes: Robust $t$-statistics in parentheses for OLS; CLOGIT grouped by state; FELOGIT includes state fixed effects and average partial effects are displayed; ${ }^{* *} \mathrm{p}<0.01,{ }^{*} \mathrm{p}<0.05$. 
ideology across all three may be the most important. This is accomplished by interacting averaged legislative majority ideology with gubernatorial ideology (CFscore) from the Database on Ideology, Money in Politics, and Elections (DIME) (Bonica 2015). Fourth, two specific and visible preemptions, minimum wage and paid leave, are estimated separately to disentangle any effects masked by their combination. Lastly, the restriction on only one preemption per year is relaxed. A number of states pass multiple preemptions per year and this last set of models explores this additional variation.

The following section examines each of these potentialities in turn. The point is not to dispute the previous results, but rather to demonstrate the durability of findings that increased conservative legislative ideology is driving legislative preemption activity. To conserve space, key coefficients are reported in Table 3 and 4, but the remaining control variables are suppressed. ${ }^{15}$ In most instances, the control variables are the same as those that appear in Table 2. Full negative binomial regression results are presented in Table 5.

\section{Chamber Ideology}

The results presented in Table 2 relates majority party ideology to preemption activity. This relationship eliminates the possibility for bipartisan preemption. It is entirely possible that more conservative chambers rather than majority parties are preempting local ordinances. This potentiality is explored in Panel A of Table 3. As can be seen, the results are uniformly positive, but significantly more fragile than the findings from Table 2 . Combined with the previous results, it is unclear that which chambers ideology is the most important. A one unit increase in senate chamber ideology is associated with a 20 percent increase in the probability of a preemption. The effect size is significantly larger than any of the results in Table 2 suggesting more conservative members of the minority party may join with the majority party to increase the probability of preemption.

\section{Combined Ideology}

Legislative chambers do not make law in isolation. Legislation passed in one chamber requires passage in the other plus a gubernatorial signature. This relationship suggests the combined or averaged ideology of the legislative body may be the more important measure of ideology. This is explored in Panel B of Table 3. Following Shor and McCarty (2011), median upper and lower chamber majority and upper and lower chamber ideology scores are averaged to provide a single, composite measure of legislative majority and chamber ideology. These composite measures iare entered into the same models presented in Table 2.

As can be seen in Panel B of Table 3, both majority and chamber ideology are positively associated with the probability of legislative preemption. The same relative size difference in effect size between majority party and chamber ideology from the previous section is preserved. A one unit increase in majority ideology is associated with a ten percent increase in the probability of preemption. This same increase in chamber ideology is associated than an effect size roughly one and a half to two times the size of the averaged majority median. These results reinforce the prior findings that conservative ideology driving preemption activity.

\footnotetext{
${ }^{15}$ For specific exemptions presented in table 4 , the previous preemptions variable is dropped from the estimation.
} 
Table 3: Extensions

\begin{tabular}{lccc}
\hline Variable & $(1)$ & $(2)$ & $(3)$ \\
\hline (A) Chamber Ideology & OLS & CLOGIT & FELOGIT \\
State house chamber median & & & \\
& 0.1006 & 2.1512 & 0.0736 \\
State senate chamber median & $(1.84)$ & $(1.59)$ & $(1.51)$ \\
& 0.0900 & $5.8631^{*}$ & $0.2013^{*}$ \\
(B) Combined Ideology & $(1.69)$ & $(2.46)$ & $(1.99)$ \\
Averaged state majority medians & & & \\
& $0.1063^{* *}$ & $3.6814^{* *}$ & $0.1323^{* *}$ \\
& $(4.06)$ & $(4.25)$ & $(2.65)$ \\
Averaged state chamber medians & $0.1748^{* *}$ & $7.1354^{* *}$ & $0.2466^{*}$ \\
& $(4.10)$ & $(4.18)$ & $(2.53)$ \\
(C) Interacted with Gubernatorial Ideology & & & \\
Averaged state majority medians & $0.1237^{* *}$ & $5.9369^{* *}$ & 0.1410 \\
& $(3.62)$ & $(2.95)$ & $(1.55)$ \\
Recipient CF score & -0.0198 & 1.1328 & 0.0342 \\
& $(0.55)$ & $(0.67)$ & $(0.91)$ \\
Majority median * recipient CF score & $0.0892^{*}$ & -0.5933 & -0.0229 \\
& $(2.62)$ & $(0.28)$ & $(0.52)$ \\
\hline
\end{tabular}

\section{Gubernatorial Ideology}

It may be the case that the results presented thus far are simply reflecting the choice of governors to sign preemption legislation. While more conservative state legislatures may produce more preemption legislation, enactment of such legislation requires a gubernatorial signature (or veto override). Indeed, there are recent examples of governors vetoing preemption legislation in the realm of worker rights. Governor Mark Dayton (MN, D) vetoed 2017 legislation to preemption Minnesota cities from adopting city ordinance pertaining to paid time off or minimum wage (StassenBerger 2017). Governors may serve as important gatekeepers, preventing or allowing preemption to proceed in line with their personal ideologies.

If the correlation between legislative ideology and probability of preemption is merely a byproduct of more conservative governors choosing to sign preemption legislation, controlling for gubernatorial ideology should cause legislative ideology to become statistically insignificant. To examine this, I introduce a new variable, winning gubernatorial candidate CFscore from the DIME data (Bonica 2013, 2015) and interact it with averaged state majority medians. These data do not cover the entire period of the analysis presented in Table 2 or 3 rather they cover the time period from 1994 to 2014. Therefore, these are not directly comparable to the other results, but serve as a useful check for alternative hypotheses. As can be seen in Panel C of Table 3, the point estimates for averaged state majority medians are roughly similar to the analogous point estimates from Panel B. Importantly, across two of the three estimation techniques, the statistical significance of the primary effect is largely preserved. Gubernatorial CFscore and its interaction is only statistically significant in the OLS specification. The results from the OLS specification suggest that in states with more liberal governors, the risk of preemption is reduced for both liberal legislative majorities and conservative majorities. Most applicable to this analysis, more liberal governors 
may temper the effect of ideologically conservative state legislatures on preemption activity. It should be noted that this result is fragile and not supported by the two other specifications.

\section{Minimum Wage \& Paid Leave}

The analysis to this point has examined all preemptions; however, this is a combination of five discrete policies. Table 4 disaggregates two politically salient targets of legislative preemption, local minimum wage ordinances and local paid leave ordinances, and re-estimates all models to this point. What is clear from Table 4 is ideology has little influence on paid leave preemption. Regardless of how ideology is operationalized, there is no statistical relationship between ideology paid leave preemption. ${ }^{16}$ Therefore, within-state increases in ideology (i.e. rising conservatism) are unlikely to be the source of legislative preemptions of local paid leave ordinances.

Turning next to legislative preemptions of local minimum wage ordinances, the association between ideology and preemption is positive. However, the results by legislative chamber are somewhat unreliable. The results are more consistent for combined ideology with both averaged majority and averaged chamber ideology positively associated with preemption. These results are somewhat smaller than the combined results presented in Table 3, but this is to be expected as the number of preemptions being predicted is smaller.

Table 4: Policy Specific Preemptions

\begin{tabular}{|c|c|c|c|c|c|c|}
\hline \multirow[b]{2}{*}{ Variable } & \multicolumn{3}{|c|}{ Minimum Wage } & \multicolumn{3}{|c|}{ Paid Leave } \\
\hline & $\begin{array}{c}(1) \\
\text { OLS }\end{array}$ & $\begin{array}{c}(2) \\
\text { CLOGIT }\end{array}$ & $\begin{array}{c}(3) \\
\text { FELOGIT }\end{array}$ & $\begin{array}{c}(4) \\
\text { OLS }\end{array}$ & $\begin{array}{c}(5) \\
\text { CLOGIT }\end{array}$ & $\begin{array}{c}(6) \\
\text { FELOGIT }\end{array}$ \\
\hline \multicolumn{7}{|l|}{ (A) Majority Ideology } \\
\hline State house majority median & $\begin{array}{c}0.0171 \\
(0.98)\end{array}$ & $\begin{array}{l}1.1095 \\
(1.16)\end{array}$ & $\begin{array}{c}0.0267 \\
(1.13)\end{array}$ & $\begin{array}{c}-0.0039 \\
(-0.19)\end{array}$ & $\begin{array}{c}-0.5286 \\
(-0.27)\end{array}$ & $\begin{array}{c}-0.0098 \\
(-0.42)\end{array}$ \\
\hline State senate majority median & $\begin{array}{c}0.0741^{* *} \\
(3.55)\end{array}$ & $\begin{array}{c}3.0491 \\
(1.93)\end{array}$ & $\begin{array}{c}0.0734 \\
(1.48)\end{array}$ & $\begin{array}{c}0.0141 \\
(0.69)\end{array}$ & $\begin{array}{l}4.7211 \\
(0.49)\end{array}$ & $\begin{array}{c}0.0846 \\
(0.65)\end{array}$ \\
\hline \multicolumn{7}{|l|}{ (B) Chamber Ideology } \\
\hline State house chamber median & $\begin{array}{c}0.0214 \\
(0.76)\end{array}$ & $\begin{array}{l}1.5025 \\
(0.83)\end{array}$ & $\begin{array}{c}0.0359 \\
(0.87)\end{array}$ & $\begin{array}{c}-0.0213 \\
(-0.58)\end{array}$ & $\begin{array}{c}-3.2575 \\
(-0.77)\end{array}$ & $\begin{array}{c}-0.0571 \\
(-0.76)\end{array}$ \\
\hline State senate chamber median & $\begin{array}{c}0.1007^{* *} \\
(3.23)\end{array}$ & $\begin{array}{c}4.2385^{*} \\
(1.99)\end{array}$ & $\begin{array}{c}0.1016 \\
(1.46)\end{array}$ & $\begin{array}{c}0.0140 \\
(0.48)\end{array}$ & $\begin{array}{l}2.3117 \\
(0.63)\end{array}$ & $\begin{array}{c}0.0409 \\
(0.73)\end{array}$ \\
\hline \multicolumn{7}{|l|}{ (C) Combined Ideology } \\
\hline Averaged state majority medians & $\begin{array}{c}0.0809 * * \\
(4.20)\end{array}$ & $\begin{array}{c}3.7253^{*} \\
(2.57)\end{array}$ & $\begin{array}{c}0.0901 \\
(1.67)\end{array}$ & $\begin{array}{c}0.0083 \\
(0.56)\end{array}$ & $\begin{array}{c}1.7740 \\
(0.42)\end{array}$ & $\begin{array}{c}0.0301 \\
(0.54)\end{array}$ \\
\hline Averaged state chamber medians & $\begin{array}{c}0.1220^{* *} \\
(4.01)\end{array}$ & $\begin{array}{c}6.2195^{*} \\
(2.52)\end{array}$ & $\begin{array}{c}0.1500 \\
(1.63)\end{array}$ & $\begin{array}{c}0.0058 \\
(0.21)\end{array}$ & $\begin{array}{c}2.4290 \\
(0.50)\end{array}$ & $\begin{array}{c}0.0420 \\
(0.62)\end{array}$ \\
\hline
\end{tabular}

Notes: Robust $t$-statistics in parentheses for OLS; ${ }^{* *} \mathrm{p}<0.01,{ }^{*} \mathrm{p}<0.05$.

\section{Count Models}

The final extension is to relax the aggregation of all preemptions into a single dichotomous variable. Rather than indicating any preemption in a given year, the number of preemptions by stateyear is the dependent variable. Doing so requires altering the estimation technique. The count

\footnotetext{
${ }^{16}$ If the state fixed effects are dropped, altering the estimation to be a between-analysis rather than a within-analysis, ideology is positively associated with paid leave preemption.
} 
nature of the dependent variable suggests uses negative binomial regression; however, the inclusion of conditional fixed effects is difficult. ${ }^{17}$ Allison and Waterman (2002) suggest including a $j-1$ series of state dummy variables and using outer product of gradient standard errors is a good approximation of conditional fixed effects. ${ }^{18}$ Given the structure of the data (see Table 1), one might expect a zero-inflated model to be appropriate. A Vuong test was conducted for each model in Table 5 and there is little evidence to suggest a zero-inflated model performs better than a normal negative binomial regression.

Table 5 shows the results of four negative binomial regression models where the dependent variable is the count of legislative preemptions of any kind in a given year. The first specification included house and senate majority ideology and the second model include house and senate chamber ideology. In both models, neither variable rises to the level of statistical significance. Moving to specification three, includes combined majority ideology and is positively and statistically significant predictor of the count of legislative preemptions. Negative binomial coefficients may be viewed as semielasticities; therefore, a one unit increase in averaged state majority ideology is associated with 310 percent more preemptions, all else equal. ${ }^{19}$ Given this median number of preemptions is zero, this large coefficient makes some sense. The effect size of fourth specification is not quite double that of the third. Taken together, increasingly conservative state legislatures are associated with an increase in the count of legislative preemptions. Similar to the primary results in Table 2, political institutions variables as well of the controls are not influential on preemption activity.

\section{Discussion \& Conclusions}

The intent of this analysis is to examine the relationship between state legislative ideology and the legislative preemption of local ordinances in the realm of worker rights policy. Using data from the Economic Policy Institute on five policies, minimum wage, fair scheduling, project labor agreements, prevailing wage, and paid leave, a state fixed-effects event history analysis is conducted with legislative ideology as the primary regressor. Through multiple regression models, an association between within state increases in legislative conservatism and preemption activity is found. Combined ideology, the average of lower and upper house median ideology, is the most consistently important measure of ideology across all models. Few other factors appear to influential. The results appear to conform to the popular narrative of more ideologically conservative state legislatures preempt policies of more ideologically liberal city governments. The findings here add to the recent work by Swanson and Barrilleaux (2018) who find a similar result with respect to court-driven preemption. Ideology appears to play an important role in the decision to involve the state in the affairs of local governments in recent decades.

A unique aspect of this analysis, the focus on legislatively-driven preemptions, is also a limitation. Because no specific local ordinance is required for legislative preemption activity to begin, it is difficult to accurately measure the ideological distance between state legislators and local officials. Should it be possible to measure, it is unclear which ideological distance would be important: state to central city, state to all cities, state to some cities? Swanson and Barrilleaux (2018)

\footnotetext{
${ }^{17}$ Fixed-effects poisson regression is also an option; however, the LR test from Table 5 suggests over-dispersion is a problem for all four models. Therefore, the estimation continues with negative binomial regression.

${ }^{18}$ This is easily implemented in Stata using the nbreg command with the vce (ogp) option.

${ }^{19}$ The incident rate ratio, $e^{\beta}$ is 22.3 suggesting relative to a state with a legislative ideology of 0 , a state with a legislative ideology of 1 will have 22.3 times the incident rate of preemptions.
} 
Table 5: Count Models

\begin{tabular}{|c|c|c|c|c|}
\hline Variable & (1) & (2) & (3) & (4) \\
\hline \multicolumn{5}{|l|}{ Ideology } \\
\hline State house majority median & $\begin{array}{c}0.9230 \\
(0.78)\end{array}$ & - & - & - \\
\hline State senate majority median & $\begin{array}{l}2.3118 \\
(1.44)\end{array}$ & - & - & - \\
\hline State house chamber median & - & $\begin{array}{c}0.7742 \\
(0.41)\end{array}$ & - & - \\
\hline State senate chamber median & - & $\begin{array}{l}4.9856 \\
(1.90)\end{array}$ & - & - \\
\hline Averaged state majority medians & - & - & $\begin{array}{c}3.1049^{*} \\
(2.52)\end{array}$ & - \\
\hline Averaged state chamber medians & - & - & - & $\begin{array}{c}5.3788^{*} \\
(2.37)\end{array}$ \\
\hline \multicolumn{5}{|l|}{ Political Institutions } \\
\hline State legislative professionalism & $\begin{array}{c}-2.6835 \\
(-0.46)\end{array}$ & $\begin{array}{c}-2.3881 \\
(-0.40)\end{array}$ & $\begin{array}{c}-2.7136 \\
(-0.50)\end{array}$ & $\begin{array}{c}-3.3855 \\
(-0.58)\end{array}$ \\
\hline Political competition & $\begin{array}{c}-11.9361 \\
(-1.75)\end{array}$ & $\begin{array}{c}-11.0478 \\
(-1.68)\end{array}$ & $\begin{array}{c}-12.4411^{*} \\
(-2.33)\end{array}$ & $\begin{array}{c}-11.9157 \\
(-1.89)\end{array}$ \\
\hline \multicolumn{5}{|l|}{ Economics \& Demographics } \\
\hline Population (1000s) & $\begin{array}{c}-0.0029 \\
(-1.11)\end{array}$ & $\begin{array}{c}-0.0023 \\
(-1.05)\end{array}$ & $\begin{array}{c}-0.0028 \\
(-1.23)\end{array}$ & $\begin{array}{c}-0.0021 \\
(-0.93)\end{array}$ \\
\hline Personal income, per capita & $\begin{array}{c}0.2023 \\
(0.87)\end{array}$ & $\begin{array}{c}0.1805 \\
(0.76)\end{array}$ & $\begin{array}{c}0.2209 \\
(1.01)\end{array}$ & $\begin{array}{c}0.2406 \\
(1.02)\end{array}$ \\
\hline Population density & $\begin{array}{c}0.0696 \\
(0.66)\end{array}$ & $\begin{array}{c}0.0574 \\
(0.59)\end{array}$ & $\begin{array}{c}0.0639 \\
(0.65)\end{array}$ & $\begin{array}{c}0.0415 \\
(0.41)\end{array}$ \\
\hline$\%$ Urban population & $\begin{array}{l}-6.2667 \\
(-0.54)\end{array}$ & $\begin{array}{c}-3.7127 \\
(-0.32)\end{array}$ & $\begin{array}{c}-6.3044 \\
(-0.58)\end{array}$ & $\begin{array}{c}-3.3179 \\
(-0.28)\end{array}$ \\
\hline$\%$ Population over 65 & $\begin{array}{c}104.4882^{*} \\
(2.08)\end{array}$ & $\begin{array}{c}98.8778 \\
(1.96)\end{array}$ & $\begin{array}{c}110.9051^{*} \\
(2.45)\end{array}$ & $\begin{array}{c}112.9562^{*} \\
(2.21)\end{array}$ \\
\hline$\%$ Population under 19 & $\begin{array}{c}21.4481 \\
(0.29)\end{array}$ & $\begin{array}{c}12.3670 \\
(0.15)\end{array}$ & $\begin{array}{c}22.3572 \\
(0.32)\end{array}$ & $\begin{array}{c}28.4750 \\
(0.36)\end{array}$ \\
\hline$\%$ College degree & $\begin{array}{r}-1.4567 \\
(-0.07)\end{array}$ & $\begin{array}{c}-4.9674 \\
(-0.21)\end{array}$ & $\begin{array}{r}-0.6530 \\
(-0.03)\end{array}$ & $\begin{array}{c}-0.3241 \\
(-0.01)\end{array}$ \\
\hline Ethnic fractionalization index & $\begin{array}{c}111.1113 \\
(1.80)\end{array}$ & $\begin{array}{c}81.8640 \\
(1.56)\end{array}$ & $\begin{array}{c}106.6171^{*} \\
(2.02)\end{array}$ & $\begin{array}{c}76.2260 \\
(1.44)\end{array}$ \\
\hline Union membership density & $\begin{array}{c}19.9902 \\
(0.82)\end{array}$ & $\begin{array}{c}9.1185 \\
(0.36)\end{array}$ & $\begin{array}{c}24.6102 \\
(1.17)\end{array}$ & $\begin{array}{c}16.0107 \\
(0.67)\end{array}$ \\
\hline Number of previous preemptions & $\begin{array}{c}-2.3259^{* *} \\
(-4.73) \\
\end{array}$ & $\begin{array}{c}-2.3170^{* *} \\
(-4.82) \\
\end{array}$ & $\begin{array}{c}-2.2962^{* *} \\
(-6.42) \\
\end{array}$ & $\begin{array}{c}-2.3273^{* *} \\
(-5.16) \\
\end{array}$ \\
\hline State fixed effects? & Yes & Yes & Yes & Yes \\
\hline $\mathrm{N}$ & 987 & 987 & 1,017 & 1,017 \\
\hline
\end{tabular}

Notes: Outer product of gradient (OPG) z-statistics in parentheses. ${ }^{* *} \mathrm{p}<0.01,{ }^{*} \mathrm{p}<0.05$. 
have a precise answer by focusing on court-driven preemption. The ideological distance between the state and the specific city being sued is important. In some legislative preemptions, no local ordinance was proposed or passed making the potential difference in state-local ideology moot. Others are a response to specific passed or proposed ordinances making the ideological distance between state and specific city important. The analysis presented here cannot disentangle this issue. A second limitation of this study is the relatively narrow, policy specific nature of the preemption data. The limited nature of the preemption data is partially out of necessity. State legislatures consider hundreds, if not thousands, of bills pertinent to local governments per year (Bowman and Kearney 2014; Gamm and Kousser 2010). Correctly identifying which of these are preemption related may be an impossible task. By reducing the scope to five specific policies, an accurate count can be established. Future research should attempt to identify a larger population of past preemptions and establish a method of tracking new ones.

Local governments rely on their relative autonomy to provide local solutions to local problems. States are well within their powers to adjust the level of autonomy provided to local governments; however, some stability in autonomy is required. If, as the results of this analysis suggest, more conservative state legislative ideology is an important predictor of preemption activity, it is entirely possible for these preemptions to be undone with changes in ideology. If local autonomy begins to change with state election cycles, local elected officials and administrators will have a difficult time planning for future events. Local government provide public services that, by their nature, require stability; services like police and fire departments, public parks, and schools. Related specifically to this analysis, local ordinances related to worker rights require local businesses to make changes to accommodate new regulations. Uncertainty over whether local business regulations will change could significantly alter business decisions and ultimately harm local economies.

As Figure 2 shows, preemption activity in the realm of worker rights laws has been accelerating over time. It is reasonable to assume preemptions in other policy areas have been accelerating as well; however, we do not have as good of data in other policy arenas. Future research should address a number of issues. First, this research should be expanded to include more policy areas. Given the visibility and salience of worker rights related preemptions, it is possible these findings are contained only to this policy area. Observing more preemptions and more varied preemptions will allow scholars to make this determination. Second, the relationship between preemption activity, regardless of kind, and local autonomy is relatively unexplored. It is clear preemption alters local autonomy, but it is unclear how much preemption reduces local autonomy or how this reduction should be reflected in relevant data on local autonomy. Sorting through these two issues in the research will enhance our ability to identify/track preemptions and examine the effects of preemption on local governments.

\section{References}

Alesina, Alberto, Reza Baqir, and William Easterly. 1999. "Public Goods and Ethnic Divisions." Quarterly Journal of Economics 114 (4): 1243-1284.

Allison, Paul D., and Richard P. Waterman. 2002. "Fixed Effects Negative Binomial Regression Models." Sociological Methodology 32 (1): 247-265.

Angrist, Joshua D. 2001. "Estimation of Limited Dependent Variable Models with Dummy Endogenous Regressors." Journal of Business E Economic Statistics 19 (1): 2-28. 
Beck, Nathaniel. 2015. "Estimating Grouped Data Models with a Binary Dependent Variable and Fixed Effects: What are the Issues?" Prepared for delivery at the Annual Meeting of the Society for Political Methodology, University of Rochester. https : / / arxiv . org / abs / 1809 . 06505.

Berman, David R. 2003. Local Government and the States: Autonomy, Politics, and Policy. Armonk, NY: M.E. Sharpe.

Berry, Frances Stokes, and William D. Berry. 1990. "State Lottery Adoptions as Policy Innovations: An Event History Analysis." American Political Science Review 84 (2): 395-415.

Berry, William D., et al. 1998. "Measuring Citizen and Government Ideology in the American States, 1960-93." American Journal of Political Science 42 (1): 327-348.

Bibby, John R., and Thomas M. Holbrook. 2004. "Parties and Elections." In Politics in the American States, ed. by Virginia H. Gray and Russell L. Hanson. Washington D.C.: CQ Press.

Boehmke, Frederick J. 2009. "Approaches to Modeling the Adoption and Diffusion of Policies with Multiple Components." State Politics \& Policy Quarterly 9 (2): 229-252.

Bonica, Adam. 2013. "Ideology and Interests in the Political Marketplace." American Journal of Political Science 57 (2): 294-311.

— . 2015. "Database on Ideology, Money in Politics, and Elections." Harvard Dataverse, V2. https://doi.org/10.7910/DVN/O5PX0B.

Boushey, Graeme. 2010. Policy Diffusion Dynamics in America. New York: Cambridge University Press.

Bowman, Ann O’M. 2017. "The State-Local Government(s) Conundrum: Power and Design." The Journal of Politics 79 (4): 1119-1129.

Bowman, Ann O'M, and Richard C. Kearney. 2011. "Second-Order Devolution: Data and Doubt." Publius: The Journal of Federalism 41 (4): 563-585.

— . 2012. "Are U.S. Cities Losing Power and Authority? Perceptions of Local Government Actors." Urban Affairs Review 48 (4): 528-546.

— . 2014. "Transforming State-Local Relations." Paper presented at the annual conference of the American Society for Public Administration, Washington, DC, March 14-18. https : / / www . bloch . umkc . edu / cookingham / documents / symposium / Bowman - Kearney ASPA2014.pdf.

Briffault, Richard. 2018. "The Challenge of the New Preemption." Columbia Public Law Research Paper No. 14-580.

Burns, Nancy, and Gerald Gamm. 1997. "Creatures of the State: State Politics and Local Government, 1971-1921." Urban Affairs Review 33 (1): 59-96.

Burns, Nancy, et al. 2009. "Urban Politics in the State Arena." Studies in American Political Development 23 (1): 1-22.

Chamberlain, Gary. 1980. "Analysis of Covariance with Qualitative Data." The Review of Economic Studies 47 (1): 225-238.

DuPuis, Nicole, et al. 2018. City Rights in an Era of Preemption: A State-by-State Analysis, 2018 Update. Washington D.C.: National League of Cities. 
Economic Policy Institute. 2018. "Worker rights preemption in the US." Accessed 26 April 2018. https://www.epi.org/preemption-map/.

Einstein, Katherine Levine, and David M. Glick. 2017. "Cities in American Federalism: Evidence on State-Local Government Conflict from a Survey of Mayors." Publius: The Journal of Federalism 47 (4): 599-621.

Frug, Gerald E., and David J. Barron. 2008. City Bound: How states Stifle Urban Innovation. Ithica: Cornell University Press.

Gamm, Gerald, and Thad Kousser. 2010. "Broad Bills or Particularistic Policy? Historical Patterns in American State Legislatures." American Political Science Review 104 (1): 151-170.

— . 2013. "No Strength in Numbers: The Failure of Big-City Bills in American State Legislatures, 1880-2000." American Political Science Review 107 (4): 663-678.

Grabar, Henry. 2016. “The Shackling of the American City." Slate, no. September 9. http : // www. slate.com/articles/business/metropolis/2016/09/how_alec_acce_ and_pre_emptions_laws_are_gutting_the_powers_of_american_cities.html.

Green, Donald P., Soo Yeon Kim, and David H. Yoon. 2001. “Dirty Pool.” International Organization 55 (2): 441-468.

Hertel-Fernandez, Alexander. 2014. “Who passes business's model bills? Policy capacity and corporate influence in U.S. state politics." Perspectives on Politics 12 (3): 582-602.

— . 2016. "Explaining Durable Business Coalitions in U.S. Politics: Conservatives and Corporate Interests across America's Statehouses." Studies in American Political Development 30 (1): 1-18.

Hicks, William D., et al. 2018. “Home Rule Be Damned: Exploring Policy Conflicts between the Statehouse and City Hall." PS: Political Science \& Politics 51 (1): 26-38.

Hirsch, Barry T., and David A. Macpherson. 2003. "Union Membership and Converage Database from the Current Population Survey: Note." Industrial and Labor Relations Review 56 (2): 349354.

Hooghe, Liesbet, and Gary Marks. 2009. “Does Efficiency Shape the Territorial Structure of Government?" Annual Review of Political Science 12 (1): 225-241.

Jansa, Joshua M., Eric R. Hansen, and Virginia H. Gray. Forthcoming. "Copy and Paste Lawmaking: Legislative Professionalism and Policy Reinvention in the States." American Politics Research.

Langan, Trevor J., and Christiana K. McFarland. 2017. "City Leadership, City Constraints." State $\mathcal{E}$ Local Government Review 49 (4): 267-274.

Lovrich, Nicholas P., and Meredith A. Newman. 2004. "The Hearing of Local Government Interests in State Legislatures: The Effects of Prior Service in City or County Government." State E Local Government Review 36 (1): 67-77.

National Restaurant Association. 2014. "New Study Shows $\$ 13$ Minimum Wage Hike Would Eliminate 11,600 Jobs in Chicago." https : / / www . restaurant . org/Pressroom/Press Releases/New-Study-Shows-\$13-Minimum-Wage-Hike-Would-Elimin.

National Retail Federation. 2014. “NRF Says Minimum Wage Hike Would Bring 'Minimum Opportunities'." https: // nrf .com/media/press-releases/nrf-says-minimumwage-hike-would-bring-minimum-opportunities. 
Neyman, J., and Elizabeth L. Scott. 1948. “Consistent Estimates Based on Partially Consistent Observations." Econometrica 16 (1): 1-32.

Phillips, Lauren E. 2017. “Impeding Innovation: State Preemption of Progressive Local Regulations." Columbia Law Review 117 (8): 2225-2263.

Richardson, Jesse J. 2011. "Dillon's Rule is From Mars, Home Rule is From Venus: Local Government Autonomy and the Rules of Statutory Construction." Publius: The Journal of Federalism 41 (4): 662-685.

Riverstone-Newell, Lori. 2017. "The Rise of State Preemption Laws in Response to Local Policy Innovation." Publius: The Journal of Federalism 47 (3): 403-425.

Schneider, Saundra K., William G. Jacoby, and Daniel C. Lewis. 2011. “Public Opinion Toward Intergovernmental Policy Responsibilities." Publius: The Journal of Federalism 41 (1): 1-30.

Shipan, Charles R., and Craig Volden. 2008. "The Mechanisms of Policy Diffusion." American Journal of Political Science 52 (4): 840-857.

Shor, Boris, and Nolan McCarty. 2011. "The Ideological Mapping of American Legislatures." American Political Science Review 105 (3): 530-551.

Squire, Peverill. 1992. "Legislative Professionalization and Membership Diversity in State Legislature." Legislative Studies Quarterly 17 (1): 69-79.

— . 2000. "Uncontested Seats in State Legislative Elections." Legislative Studies Quarterly 25 (1): 131-146.

— . 2007. "Measuring State Legislative Professionalism: The Squire Index Revisited." State Politics $\mathcal{E}$ Policy Quarterly 7 (2): 211-227.

— . 2012. The Evolution of American Legislatures: Colonies, Territories and States, 1619-2009. Ann Arbor: University of Michigan Press.

— . 2017. “A Squire Index Update.” State Politics \& Policy Quarterly 17 (4): 361-371.

Stassen-Berger, Rachel E. 2017. “Mark Dayton vetoes bill curtailing cities' paid-time off, minimum wage rules." Pioneer Press, no. May 30. https : / /www.twincities.com/2017/05/30/ mark-dayton-vetoes-bill-curtailing-cities-paid-time-off-minimumwage-rules/.

Stephens, G. Ross. 1974. "State Centralization and the Erosion of Local Autonomy." The Journal of Politics 36 (1): 44-76.

Swanson, Jeffrey, and Charles Barrilleaux. 2018. "State Government Preemption of Local Government Decisions Through the State Courts." Urban Affairs Review.

Swindell, David, Carl Stenberg, and James H. Svara. 2017. "Naviating the Waters Between Local Autonomy and State Preemption." Research Report, Alliance for Innovation. https : / / urbaninnovation . asu . edu / content / navigating-waters - between- localautonomy-and-state-preemption.

Swindell, David, James H. Svara, and Carl Stenberg. 2018. "Local Government Options in the Era of State Preemption." Local Government Review: 8-13.

Trapenberg Frick, Karen, David Weinzimmer, and Paul Waddell. 2015. “The Politics of Sustainable Development Opposition: State Legislative Efforts to Stop the United Nation's Agenda 21 in the United States." Urban Studies 52 (2): 209-232. 
Vigdor, Jacob L. 2002. “Interpreting Ethnic Fragmentation Effects.” Economics Letters 75 (2): 271276. 